\title{
Biokaasulaitoksen käsittelyjäännös nurmen ja ohran lannoitteena
}

\author{
Maarit Hyrkäs ${ }^{1)}$, Perttu Virkajärvi ${ }^{1)}$, Mari Räty ${ }^{1)}$, Sari Luostarinen ${ }^{2)}$ ja Ville Pyykkönen ${ }^{1)}$ \\ 1) MTT, Kotieläintuotannon tutkimus, Halolantie 31 A, 71750 Maaninka, etunimi.sukunimi(at)mtt.fi \\ 2) MTT, Kasvintuotannon tutkimus, Latokartanonkaari 9, 00790 Helsinki, etunimi.sukunimi(at)mtt.fi
}

\section{Tiivistelmä}

MTT Maaningalla tutkittiin vuosina 2009-2012 raakalannan, biokaasulaitoksen käsittelyjäännöksen ja jäännöksestä separoitujen kuiva- ja nestejakeiden käyttöarvoa nurmen ja ohran lannoitteena. Kenttäkokeet toteutettiin nurmelle ja ohralle erikseen, ja niissä verrattiin orgaanisia lannoitteita väkilannoitteena annettuun typpeen ja fosforiin. Nurmikoe oli nelivuotinen sisältäen perustamisvuoden suojaviljan (ohra), ohrakokeen tulokset ovat kolmelta vuodelta.

Raakalanta ja käsittelyjäännös sijoitettiin 5-7 cm syvyyteen. Kuiva- ja nestejakeet levitettiin käsin pintaan ja kuivajae mullattiin äestämällä. Orgaaniset lannoitteet annettiin ohralle keväällä ja nurmelle toiselle sadolle. Lisäksi kokeessa oli kuusi erilaista väkilannoitteena annettua typpitasoa. Niiden avulla muodostettiin typen satovastefunktiot, joihin orgaanisten lannoitteiden typen hyväksikäyttöä verrattiin. Syksyisin otettiin maanäytteet kolmesta eri syvyydestä.

Ohrakokeessa käsittelyjäännöksellä saatiin yhtä suuret sadot kuin vastaavalla liukoisen typen määrällä väkilannoitteessa, paitsi kuivana vuonna 2010, jolloin sato oli $10 \%$ alhaisempi. Raakalannalla sadon määrä oli vain $85 \%$ väkilannoitteeseen verrattuna. Separoinnista ja jakeiden käytöstä ei näyttänyt olevan ohralle erityistä hyötyä. Nurmikokeessa kuivuus aiheutti suuremman eron typen hyväksikäytössä kuin biokaasuprosessi tai separointi: kuivana vuonna raakalanta ja käsittelyjäännös tuottivat selkeästi väkilannoitetta heikomman tuloksen, mutta nestejakeella vastaavaa eroa ei havaittu. Raakalannalla ja käsittelyjäännöksellä ei ollut eroa lannoitusvaikutuksessa. Molemmissa kokeissa orgaanisten lannoitteiden sijoittaminen hillitsi helppoliukoisen fosforin rikastumista maan pintakerrokseen.

Ohralla typen taseet olivat pääasiassa positiivisia, ja käsittelyjäännöksen tase oli raakalantaa alhaisempi kahtena vuonna. Nurmella ensimmäisen sadon taseet olivat tyypillisesti negatiivisia, mikä vaikutti myös kokonaissadon taseisiin. Nurmiruuduilla käsittelyjäännös tuotti raakalantaa alhaisemman typpitaseen ainoastaan vuonna 2012, jolloin sen liukoisen typen osuus kokonaistypestä oli suurempi kuin raakalannalla. Nestejakeella lannoitetut ruudut saivat enemmän kokonaistyppeä kuin muut koejäsenet, mikä näkyi positiivisina taseina joka vuosi. Myös fosforitaseet poikkesivat selvästi kasvilajien välillä. Ohralla fosforitase oli lähes aina positiivinen, myös väkilannoiteruuduilla, kun nurmella P-tase oli lähes poikkeuksetta negatiivinen.

Orgaanisten lannoitteiden lannoitusvaikutus, ravinnetaseet sekä maaperän typpikierto ovat selvästi erilaisia nurmenviljelyssä kuin viljanviljelyssä. Tämä selittyy pääosin viljelytekniikan eroilla (mm. lannoitus- ja korjuukertojen määrät, jyvien tai koko kasvuston korjuu) sekä kasvien erilaisella ravinteidenottokyvyllä. Tämän kokeen perusteella käsittelyjäännöksen edut tulevat selvemmin esiin ohran- kuin nurmenviljelyssä.

\section{Asiasanat}

fosfori, käsittelyjäännös, nurmi, ohra, raakalanta, ravinnetase, separointi, typpi 


\section{Johdanto}

Kotieläintalouden tuotantoyksikkökokojen kasvu ja niiden keskittyminen tietyille alueille ovat johtaneet tilalla syntyvän lantamäärän kasvuun sekä lannan alueelliseen ja paikalliseen keskittymiseen. Tilan omat pellot eivät välttämättä riitä vastaanottamaan syntyvää lantamäärää, ja lisämaan hankkiminen tai vastaanottosopimukset naapuritilojen kanssa ovat mahdollistaneet lannan levittämisen suuremmalle peltopinta-alalle. Lantaravinteiden hyötykäytön lisäämisessä keskeiseksi kysymykseksi on noussut lantalogistiikan kehittäminen (sisältäen mm. kuljetuksen, levityksen ja sen oikea-aikaisuuden) siten, että lanta voidaan levittää riittävän suurelle peltoalalle kustannusten pysyessä kohtuullisina.

Biokaasuprosessi on biologinen menetelmä, jossa hyödynnetään myös lannan sisältämä energiapotentiaali. Lanta hajotetaan mikrobiologisesti hapettomissa (anaerobisissa) olosuhteissa, ja lopputuotteina syntyy biokaasuprosessin käsittelyjäännöstä ja pääosin metaania ja hiilidioksidia sisältävää kaasuseosta, biokaasua. Käsittelyjäännös voidaan edelleen hyödyntää peltoviljelykäytössä ja biokaasu taas lämpönä, sähkönä tai puhdistettuna liikennepolttoaineena (Luostarinen ym. 2011; Luostarinen \& Pyykkönen 2013). Jakeistukseen pohjautuvilla fysikaalisilla menetelmillä ja saostukseen pohjautuvilla kemiallisilla menetelmillä pyritään puolestaan konsentroimaan lannan fosfori kiintoaineeseen ja vähentämään kuljetettavan lieteseoksen sisältämän veden määrää; typpipitoinen nestejae voidaan levittää tilan lähellä oleville pelloille ja fosforipitoinen kuivajae kuljettaa kauemmaksi peltolohkoille (Luostarinen ym. 2011, Paavola ym. 2011). Lannan prosessointi voi lisätä lannan hyödynnettävyyttä peltolannoituksessa. Lannan sisältämien ravinteiden ja energian tehokas hyväksikäyttö on edellytyksenä niin kestävälle elintarviketuotannolle kuin maatalouden ravinnekuormituksen vähentämiselle.

Tutkimuksen tavoitteena oli selvittää raa'an naudan lietelannan, samaa lantaa ja kasvibiomassoja käsittelevän biokaasulaitoksen käsittelyjäännöksen sekä käsittelyjäännöksestä separoitujen neste- ja kuivajakeiden käyttöarvoa nurmen ja ohran tuotannossa verrattuna väkilannoitetyppeen. Tulosten perusteella saatiin lisää tutkittua tietoa orgaanisten lannoitteiden mahdollisuuksista lannan käytön tehostamisessa ja väkilannoitteiden korvaajana tilakohtaisissa ratkaisuissa.

\section{Aineisto ja menetelmät}

Raakalannan, biokaasulaitoksen käsittelyjäännöksen ja jäännöksestä separoitujen kuiva- ja nestejakeiden käyttöarvoa nurmen ja ohran lannoitteena tutkittiin kenttäkokein Maa- ja elintarviketalouden tutkimuskeskuksen Maaningan toimipisteessä Pohjois-Savossa vuosina 2009-2012. Kenttäkokeet toteutettiin nurmelle ja ohralle erikseen lohkoittain satunnaistettuina kokeina, joissa oli neljä kerrannetta eli lohkoa. Ohrakoe toteutettiin kolmena vuonna (2009-2011; lajike Voitto), joista ensimmäisenä eri kohdassa peltolohkoa kuin kahtena jälkimmäisenä. Nurmikoe perustettiin 2009 timoteinurminataseoksena (Tuure/Ilmari 70:30) suojaviljaan (Voitto-ohra). Koe oli nelivuotinen sisältäen kolme nurmivuotta.

Kokeessa käytettiin biokaasulaitoksen esisäiliöstä otettua raakalantaa ja jälkikaasualtaan jälkeisestä kaivosta otettua käsittelyjäännöstä. Vuonna 2009 raakalannan ja jäännöksen toimitti Metener Oy, muina vuosina käytettiin MTT Maaningan tutkimusnavetan lietelantaa ja biokaasulaitoksen jäännöstä. On huomattava, ettei käsittelyjäännös ole välttämättä peräisin ravinnepitoisuuksiltaan samanlaisesta raakalannasta kuin kokeessa käytetty raakalanta, sillä lannan ominaisuudet vaihtelevat. Kokeen lanta ja jäännös otettiin samana päivänä, joten lanta oli erilaista kuin jäännöksen muodostanut lanta, joka syötettiin laitokseen noin 50 päivää (laitoksen viipymä) aiemmin. Lisäksi laitokseen syötettiin lannan lisäksi erilaisia lisäsyötteitä: makeistehtaan jätettä (2009), sipulimassaa (2010), ruokohelpisäilörehua (2011) ja timoteinurminatasäilörehua (2012). Tämän vuoksi kokeen lanta ja jäännös eivät ole ominaisuuksiltaan suoraan verrattavissa, eivätkä niiden ammoniumtypen pitoisuudet kerro biokaasuprosessissa tapahtuvasta typen mineralisaatiosta. Kaikkina vuosina käsittelyjäännöksestä separoitiin kuiva- ja nestejaetta ruuvikuivaimella (Bauer separaattori S 655), käyttäen $1 \mathrm{~mm}: \mathrm{n}$ seulakokoa. Ohrakokeella jakeita käytettiin kahdella eri tavalla: kuivajaetta joko täydennettiin kylvövaiheessa Suomensalpietarilla tai levitettiin lisäksi nestejaetta orastumisvaiheessa. Nurmikokeella kuivajaetta käytettiin perustamisvuonna, ja nurmivuosina lannoitettiin nestejakeella.

Nurmen ensimmäinen sato lannoitettiin väkilannoitteilla (100 kg N/ha), ja lannoituskäsittelyt tehtiin toiselle sadolle. Molemmissa kokeissa raakalanta ja käsittelyjäännös levitettiin omavalmisteisella $1 \mathrm{~m}^{3}$ :n vetoisella, kaksoiskiekkovantaisella kontilla ja sijoitettiin 5-7 cm syvyyteen. Kuiva- ja nestejakeet levitettiin käsin pintaan ja kuivajae mullattiin äestämällä. Lisäksi kokeessa oli kuusi erilaista väkilannoitteena annettua typpitasoa. Kontrolliportaat tarvittiin, koska liukoisen typen levitys- 
määrän täsmääminen yhtä suureksi kaikilla orgaanisilla lannoitteilla oli teknisesti mahdotonta. Orgaanisista lannoitteista otettiin edustavat näytteet levityshetkellä ja ne analysoitiin Viljavuuspalvelu Oy:ssa. Toteutuneet levitysmäärät selvitettiin punnitsemalla. Ohrakokeelle raakalantaa ja käsittelyjäännöstä levitettiin keskimäärin 35 tn/ha, kuivajaetta 16 tn/ha (vuonna $20093 \mathrm{tn} / \mathrm{ha}$ ) ja nestejaetta keskimäärin 26 tn/ha. Nurmikokeelle levitettiin perustamisvuonna $21 \mathrm{tn} /$ ha raakalantaa, $30 \mathrm{tn} / \mathrm{ha}$ käsittelyjäännöstä ja 19 tn/ha kuivajaetta. Nurmivuosina levitettiin keskimäärin 29 tn/ha raakalantaa, 26 tn/ha käsittelyjäännöstä ja 50 tn/ha nestejaetta.

Ohrasta määritettiin ruutusato, hehtolitrapaino, tuhannen jyvän paino sekä kasvuston korkeus. Jyvien typpi- ja fosforipitoisuus analysoitiin Viljavuuspalvelu Oy:ssa. Nurmiruuduilta määritettiin sato ja otettiin analyysinäyte. Näytteistä analysoitiin D-arvo, ligniini, neutraalidetergenttikuitu (NDF) ja raakavalkuainen NIR-menetelmällä sekä pääkivennäiset (Luh Huang \& Schulte 1985). Kokoviljan Darvo määritettiin sellulaasisulavuuden ja tuhkan avulla. Nurmikokeen näytteet analysoitiin MTT:n laboratorioissa Jokioisilla. Säähavainnot saatiin MTT Maaningalla sijaitsevalta Ilmatieteen laitoksen sääasemalta. Lisäksi maasta mitattiin lämpötilaa sekä kosteutta kasvukauden ajan.

Koeruuduilta otettiin syksyisin maanäytteet kolmesta eri syvyydestä $(0-2 \mathrm{~cm}, 2-10 \mathrm{~cm}$ ja 10-25 cm). Maanäytteistä määritettiin pH maa-vesisuspensiosta (v/v 1:2,5), orgaanisen kokonaishiilen ja kokonaistypen pitoisuudet kuivapolttomenetelmällä sekä happamaan ammoniumasetaattiin $(\mathrm{pH}$ 4,65 ) uuttuvan helppoliukoisen fosforin, kaliumin, kalsiumin ja magnesiumin pitoisuudet (Vuorinen \& Mäkitie 1955). Lisäksi määritettiin maan mineraalitypen (ammonium $\mathrm{NH}_{4}-\mathrm{N}$ - ja nitraattityppi $\mathrm{NO}_{3}-\mathrm{N}$ ) ja liukoisen kokonaistypen (TSN) määrä ( $2 \mathrm{M} \mathrm{KCl} ; 2 \mathrm{~h}$, uuttosuhde 1:5). Liukoinen orgaaninen typpi (SON) laskettiin liukoisen kokonaistypen (autoklavoitu suodos) ja $\mathrm{NH}_{4}-\mathrm{N}: \mathrm{n}$ ja $\mathrm{NO}_{3}-\mathrm{N}: n$ erotuksena.

Tilastollinen analysointi tehtiin SAS 9.2.-ohjelmiston Mixed-proseduurilla. Vuodet ja niitot analysoitiin aina erikseen. Lannoituskäsittely oli mallissa kiinteänä tekijänä ja kerranne satunnaisena. Parivertailut tehtiin kontrastien avulla. Orgaanisten lannoitteiden liukoisen typen hyväksikäyttökykyä verrattiin vastaavaan väkilannoitetyppeen muodostamalla typpiporrastulosten avulla vuosittain typen satovastefunktiot (toisen, kolmannen tai neljännen asteen polynomit). Tämä vertailu tehtiin Excelillä. Syksyn maanäytteiden tulokset analysoitiin Mixed-mallilla, jossa kiinteinä tekijöinä olivat lannoituskäsittely, näytteenottosyvyys ja näiden yhdysvaikutus ja satunnaisina tekijöinä kerranne ja kerranne*näytteenottosyvyys-yhdysvaikutus. Näytteenottosyvyys oli toistotekijä Toeplizkovarianssirakenteella. Parivertailut tehtiin kontrastien avulla. Poikkeavia havaintoja poistettiin analyysistä tarvittaessa.

\section{Tulokset ja tulosten tarkastelu}

\section{Sää}

Kuvassa 1 esitetään koevuosien sademäärät ja keskilämpötilat kuukausittain. Vuonna 2010 heinäkuu oli poikkeuksellisen kuiva ja lämmin, mikä vaikutti selvästi kasvuun. Heinäkuut vuosina 2011 ja 2012 olivat sitä vastoin normaalia sateisempia, kuten myös vuoden 2012 kesäkuu. Loppukesät olivat kaikkina vuosina 30 vuoden keskiarvoa lämpimämpiä.

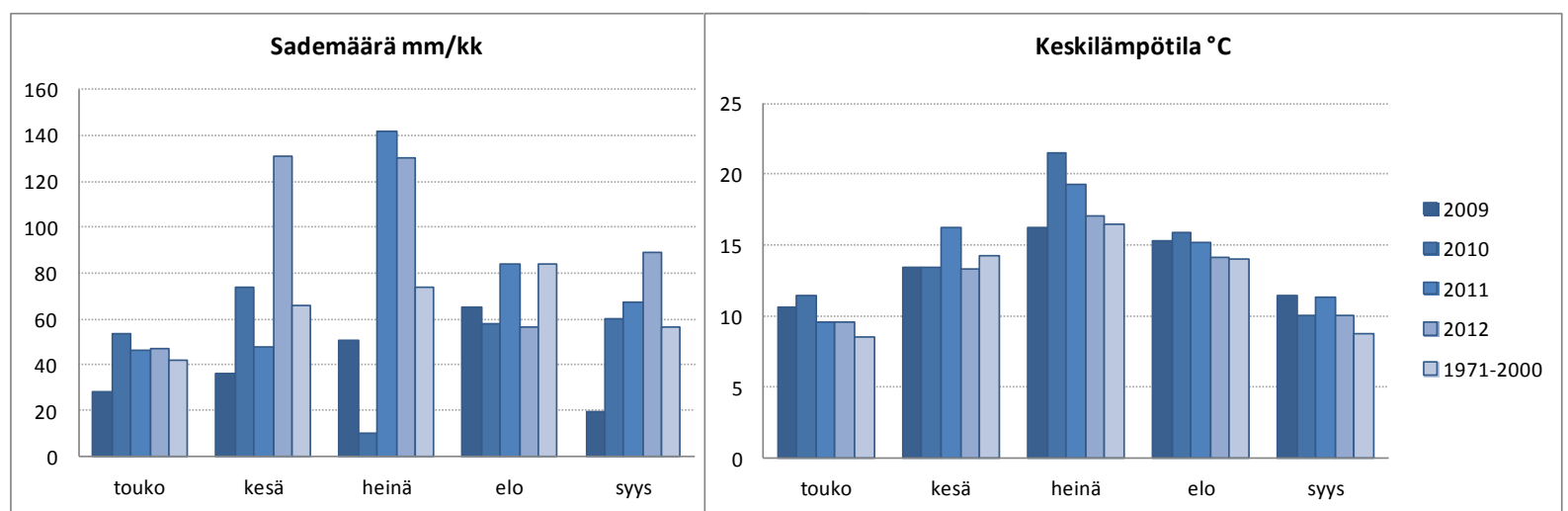

Kuva 1. Koevuosien sademäärät ja keskilämpötilat kuukausittain verrattuna 30 vuoden keskiarvoon. 


\section{Orgaaniset lannoitteet}

Tässä kokeessa käytettyjen orgaanisten lannoitteiden keskimääräiset ravinnepitoisuudet esitetään taulukossa 1. Vuosien välillä oli huomattavaa vaihtelua. Ruuvikuivainseparointi ei erotellut typpeä ja fosforia toivotulla tavalla: fosforin lisäksi myös typen osuus kuivajakeessa kasvoi, eikä fosforin osuus nestejakeessa juurikaan vähentynyt.

Taulukko 1. Kokeissa käytettyjen orgaanisten lannoitteiden keskimääräiset ravinnepitoisuudet (keskiarvo \pm keskihajonta yli vuosien 2009-2012).

\begin{tabular}{lcccccc} 
& $\begin{array}{c}\text { Kok. N } \\
\mathrm{kg} / \mathrm{tn}\end{array}$ & $\begin{array}{c}\text { Liuk. } \\
\mathrm{kg} / \mathrm{tn}\end{array}$ & Liuk-N:Kok-N & $\begin{array}{c}\text { Kuiva-aine } \\
\%\end{array}$ & $\begin{array}{c}\mathbf{P} \\
\mathrm{kg} / \mathrm{tn}\end{array}$ & $\begin{array}{c}\text { K } \\
\mathrm{kg} / \mathrm{tn}\end{array}$ \\
\hline Raakalanta & $3,0 \pm 0,8$ & $1,7 \pm 0,3$ & $0,57 \pm 0,09$ & $7,2 \pm 2,7$ & $0,50 \pm 0,14$ & $3,0 \pm 0,7$ \\
Käsittelyjäännös & $2,8 \pm 0,4$ & $1,7 \pm 0,3$ & $0,60 \pm 0,14$ & $4,7 \pm 0,7$ & $0,46 \pm 0,08$ & $3,7 \pm 0,7$ \\
Kuivajae & $5,3 \pm 0,3$ & $1,6 \pm 0,4$ & $0,30 \pm 0,06$ & $25,8 \pm 4,9$ & $1,42 \pm 0,51$ & $3,0 \pm 0,5$ \\
Nestejae & $3,1 \pm 0,8$ & $1,7 \pm 0,4$ & $0,59 \pm 0,18$ & $3,8 \pm 0,4$ & $0,44 \pm 0,07$ & $3,4 \pm 0,6$ \\
\hline
\end{tabular}

$\mathrm{n}=6$, paitsi kuivajae $\mathrm{n}=3$

\section{Liukoisen typen hyväksikäyttökyky}

Vuosien välillä oli vaihtelua keskimääräisessä satotasossa sääoloista ja korjuun ajoituksesta johtuen. Ohralla orgaanisten lannoitteiden tuottama keskimääräinen sato (15\% kosteuteen suhteutettuna) oli vuonna 20093900 kg/ha, vuonna 20102600 kg/ha ja vuonna 20112900 kg/ha. Nurmella kesän kokonaissato orgaanisilla lannoitteilla oli vuonna 2009 keskimäärin $4700 \mathrm{~kg} \mathrm{ka} / \mathrm{ha}$ (kokovilja), vuonna $20108500 \mathrm{~kg} \mathrm{ka} / \mathrm{ha}$, vuonna $201111600 \mathrm{~kg} \mathrm{ka} / \mathrm{ha}$ ja vuonna $201211100 \mathrm{~kg} \mathrm{ka} / \mathrm{ha}$.

Kokeissa haluttiin selvittää, onko orgaanisten lannoitteiden liukoisen typen hyväksikäyttökyky väkilannoitetypen veroista. Taulukossa 2 esitetään kunkin orgaanisen lannoitteen typen hyväksikäyttökyvyt vuosittain verrattuna väkilannoitetyppeen. Nämä on laskettu vertaamalla orgaanisen lannoitteen tuottamaa satomäärää siihen satomäärään, joka typpiportaiden avulla muodostettu satofunktio antaa samalla liukoisen typen määrällä.

Ohrakokeessa käsittelyjäännöksellä saatiin vuosina 2009 ja 2011 yhtä suuret sadot kuin vastaavalla liukoisen typen määrällä väkilannoitteessa. Typen hyväksikäyttö oli heikompaa vuonna 2010, jolloin varsinkin heinäkuu oli ennätyskuiva. Raakalannalla sadon määrä oli keskimäärin vain $85 \%$ väkilannoitteeseen verrattuna. Käsittelyjäännöksen separoinnista ja jakeiden käytöstä ei näyttänyt tässä kokeessa olevan ohralle hyötyä.

Taulukko 2. Orgaanisten lannoitteiden liukoisen typen hyväksikäyttö (\%) verrattuna vastaavaan väkilannoitetyppeen. Vuosisarakkeissa tähdellä merkityt eivät yltäneet vastaavaan väkilannoitetasoon (95\% luottamusväli ei leikannut väkilannoitefunktiota).

\begin{tabular}{|c|c|c|c|c|c|}
\hline OHRA & 2009 & 2010 & 2011 & & Keskimäärin \\
\hline Raakalanta & $83^{*}$ & $87^{*}$ & $86^{*}$ & & 85 \\
\hline Käsittelyjäännös & 104 & $90 *$ & 101 & & 98 \\
\hline Kuivajae + $40 \mathrm{~kg} / \mathrm{ha} \mathrm{N}$ & - & $86^{*}$ & 90 & & 88 \\
\hline Kuivajae + nestejae & $78^{*}$ & $82 *$ & 91 & & 84 \\
\hline NURMI & $\begin{array}{c}\text { kokovilja } \\
\mathbf{2 0 0 9} \\
\end{array}$ & $\begin{array}{c}\text { 1.nurmiv. } \\
\mathbf{2 0 1 0}\end{array}$ & $\begin{array}{c}\text { 2. nurmiv. } \\
\mathbf{2 0 1 1} \\
\end{array}$ & $\begin{array}{c}\text { 3. nurmiv. } \\
\mathbf{2 0 1 2} \\
\end{array}$ & Keskimäärin \\
\hline Raakalanta & 95 & $88^{*}$ & 103 & 93 & 95 \\
\hline Käsittelyjäännös & 90 & $84 *$ & 100 & 98 & 93 \\
\hline Kuivajae & 91 & - & - & - & 91 \\
\hline Nestejae & - & 101 & 103 & 93 & 99 \\
\hline Väkilannoite & 100 & 100 & 100 & 100 & 100 \\
\hline
\end{tabular}

Nurmikokeessa sääolot aiheuttivat suuremman eron typen hyväksikäytössä kuin biokaasuprosessi 
separointi: kuivana vuonna 2010 raakalanta ja käsittelyjäännös tuottivat selkeästi väkilannoitetta heikomman tuloksen, mutta nestejakeella vastaavaa eroa ei havaittu. Toisin kuin ohralla, raakalannalla ja käsittelyjäännöksellä ei ollut eroa liukoisen typen hyväksikäyttökyvyssä. On kuitenkin huomattava, että lannoitusvaikutukseen vaikuttaa liukoisen typen käyttökelpoisuuden lisäksi myös sen osuus kokonaistypestä. MTT Maaningan biokaasulaitoksella tämän kokeen aikana suoritetuissa kokeissa havaittiin liukoisen typen määrän käsittelyjäännöksessä olevan laitokseen syötettyä raakalantaa korkeampi (Luostarinen 2013, s.80). Taulukossa 2 esitetty tarkastelu ei huomioi lannoitusvaikutuksen paranemista tätä kautta.

\section{Ravinnetaseet}

Ravinnetaseet (annettujen ravinteiden ja sadossa poistuneiden ravinteiden erotukset) kuvaavat sitä, miten tehokkaasti kasvi on kyennyt käyttämään ravinteet hyödykseen. Tavoitteena on, ettei maahan kerry pidemmällä aikavälillä runsaasti hyödyntämättä jääviä ravinteita, sillä riski niiden huuhtoutumiselle kasvaa. Maata ei voi myöskään viljellä pitkään negatiivisilla N- ja P-taseilla sen köyhtymättä.

Kuvassa 2 esitetään ohran ja nurmen typpilannoitus sekä kokonaistypestä lasketut typpitaseet. Orgaanisten lannoitteiden typpipitoisuus sekä liukoisen typen osuus kokonaistypestä vaihteli vuosittain. Myös lannoitusmäärissä oli jonkin verran vaihtelua vuosien välillä koeteknisistä syistä johtuen. Nurmella kaikki koejäsenet saivat ensimmäiselle sadolle typen väkilannoitteena.

Ohralla typpitaseet olivat pääasiassa positiivisia. Vuonna 2009 ohra käytti kaiken liukoisen typen, mutta varsinkin kuivana vuonna 2010 myös liukoista typpeä jäi käyttämättä kaikilla orgaanisilla lannoitteilla. Käsittelyjäännöksen tase oli raakalantaa alhaisempi vuosina 2009 ja 2011 ( p<0,001 ja p<0,001). Käsittelyjäännöksen typpi oli siis paremmin hyödynnettävissä kuin raakalannan.

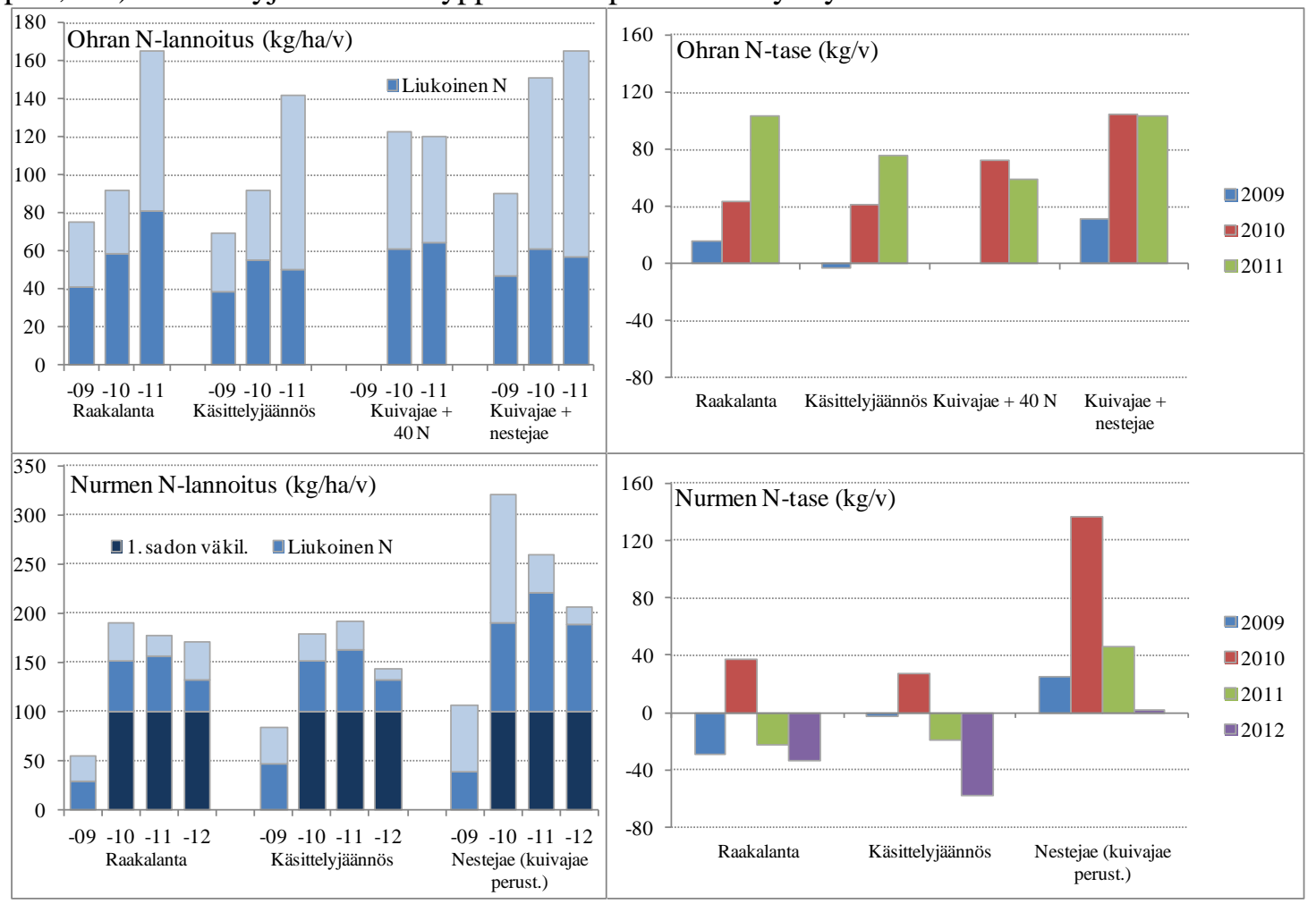

Kuva 2. Ohran ja nurmen typpilannoitusmäärät $(\mathrm{kg} / \mathrm{ha} / \mathrm{v})$ jaoteltuna 1. sadon väkilannoitetyppeen sekä orgaanisen lannoitteen liukoiseen ja muuhun osaan. Oikealla typpitaseet $(\mathrm{kg} / \mathrm{ha})$ vuosittain. Vuonna 2009 nurmen sijaan korjattiin suojavilja.

Nurmella ensimmäisen sadon taseet olivat tyypillisesti voimakkaasti negatiivisia, mikä vaikutti myös kokonaissadon taseisiin. Käsittelyjäännös tuotti raakalantaa alhaisemman typpitaseen ainoastaan vuonna 2012 ( $\mathrm{p}=0,017)$, jolloin sen liukoisen typen osuus kokonaistypestä oli suurempi kuin raakalannalla. Nestejakeella lannoitetut ruudut saivat enemmän kokonaistyppeä kuin muut koejäsenet, mikä näkyi positiivisina taseina joka vuosi. Vuonna 2010 ylitettiin nitraattidirektiivin sallima kokonaistyppiraja (170 kg N/ha), koska nestejakeen kokonaistyppimäärä oli selkeästi keskimääräistä korkeampi $(4,4 \mathrm{~kg} / \mathrm{tn})$. Vuosittaiset erot ravinnepitoisuuksissa näkyvät hyvin verrattaessa vuosien $2010 \mathrm{ja} 2011$ 
nestejakeena annettua N-lannoitusta. Levitetty määrä oli täsmälleen sama (50 tn/ha), ja ero pylväiden korkeudessa tulee ainoastaan lietteen typpipitoisuudesta. Vuoden 2010 typpitase poikkeaa muista nurmivuosista. Tämä johtuu pääasiassa siitä, että vuosina 2011 ja 2012 ensimmäinen niitto tehtiin melko myöhään, jolloin satotaso ja sen myötä typen poistuma olivat vuotta 2010 korkeammat.

Myös fosforitaseissa ero kasvilajien välillä oli selkeä. Kuvassa 3 esitetään orgaanisina lannoitteina annetun fosforin määrä sekä fosforitaseet vuosittain ohralla ja nurmella. Naudanlannan fosforin on todettu olevan lannoitusvaikutukseltaan väkilannoitefosforin veroista (Ylivainio \& Turtola 2009). Ohralla fosforitase oli lähes aina positiivinen, myös väkilannoiteruuduilla, kun taas nurmella P-tase oli lähes poikkeuksetta negatiivinen. Vuonna 2009 suurempi satotaso pienensi ohran fosforitaseita.

Kun huomioidaan, että vuonna 2009 korjattiin kokovilja, kaksi kertaa kesässä niitettävä nurmi otti maasta niin paljon fosforia, ettei sitä taseiden perusteella päässyt kumuloitumaan maahan. Ensimmäiselle sadolle nurmiruudut eivät saaneet fosforia ollenkaan, joten taseet ensimmäisessä sadossa olivat voimakkaasti negatiivisia (orgaanisilla lannoitteilla keskimäärin -16 kg). Separoidun nestejakeen P-tase oli jokaisena vuonna raakalantaa ja käsittelyjäännöstä korkeampi. Perustamisvuonna tämä koejäsen sai kuivajaetta, joka näkyy kuvassa korkeamman fosforipitoisuutensa takia selvästi korkeimpana taseena.

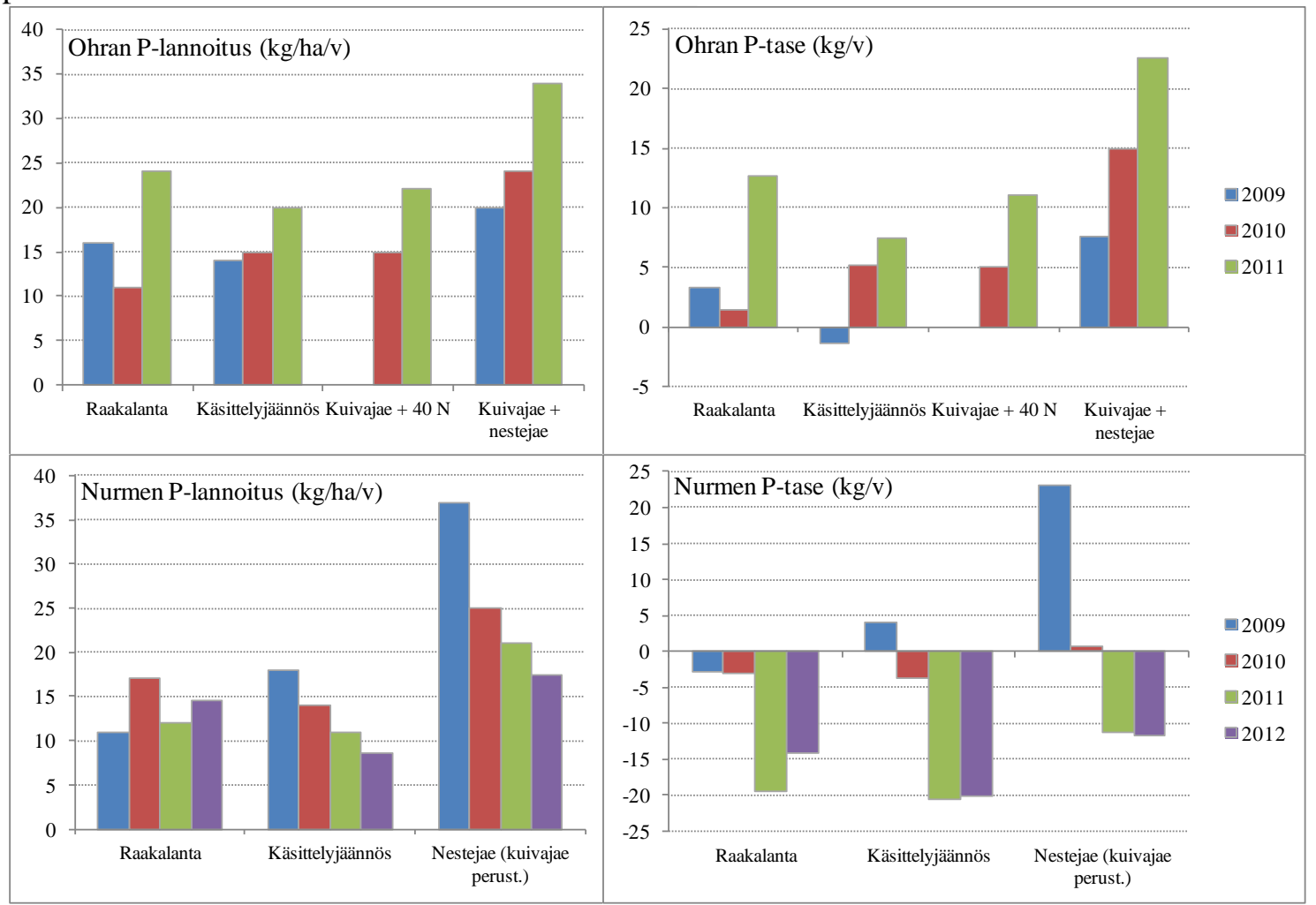

Kuva 3. Ohran ja nurmen fosforilannoitusmäärät $(\mathrm{kg} / \mathrm{ha} / \mathrm{v})$ sekä fosforitaseet $(\mathrm{kg} / \mathrm{ha})$ vuosittain erilaisilla orgaanisilla lannoitteilla. Vuonna 2009 nurmen sijaan korjattiin suojavilja.

\section{Maanäytteet}

Helppoliukoisen fosforin pitoisuudet pienenivät syvyyden suhteen, ja olivat muutamaa poikkeusta lukuun ottamatta suurempia maan 0-2 cm:n pintakerroksessa kuin vastaavasti syvemmällä $2-10$ ja 10-25 cm:n maakerroksissa. Annetun fosforimäärän lisäksi myös levitystapa selittää käsittelyiden välisiä eroja. Molemmissa kokeissa orgaanisten lannoitteiden sijoittaminen hillitsi helppoliukoisen fosforin rikastumista maan pintakerrokseen, sillä määrät eivät nousseet samalle tasolle kuin mitä esimerkiksi Uusi-Kämppä ja Heinonen-Tanski (2008) havaitsivat pintaan levitetyn lietteen tilanteessa.

Valtaosa maan kokonaistypestä oli orgaanista liukenematonta typpeä, ja koeruuduilla kokonaistypestä vain muutama prosentti oli KCl-uuttoisessa muodossa. Nurmella liukoinen kokonaistyppi (TSN) muodostui pääosin liukoisesta orgaanisesta typestä (SON), ja kasveille käyttökelpoisen mineraalitypen $\left(\mathrm{NH}_{4}-\mathrm{N}+\mathrm{NO}_{3}-\mathrm{N}\right)$ osuus TSN:stä oli huomattavasti pienempi kuin vastaavasti ohralla (Kuva 4), mikä kuvastaa nurmen tehokasta ravinteiden ottoa. Ohralla lähes kaikki mineraalityppi oli nitraattimuodossa, kun taas nurmella se oli pääsääntöisesti ammoniumtyppeä. 


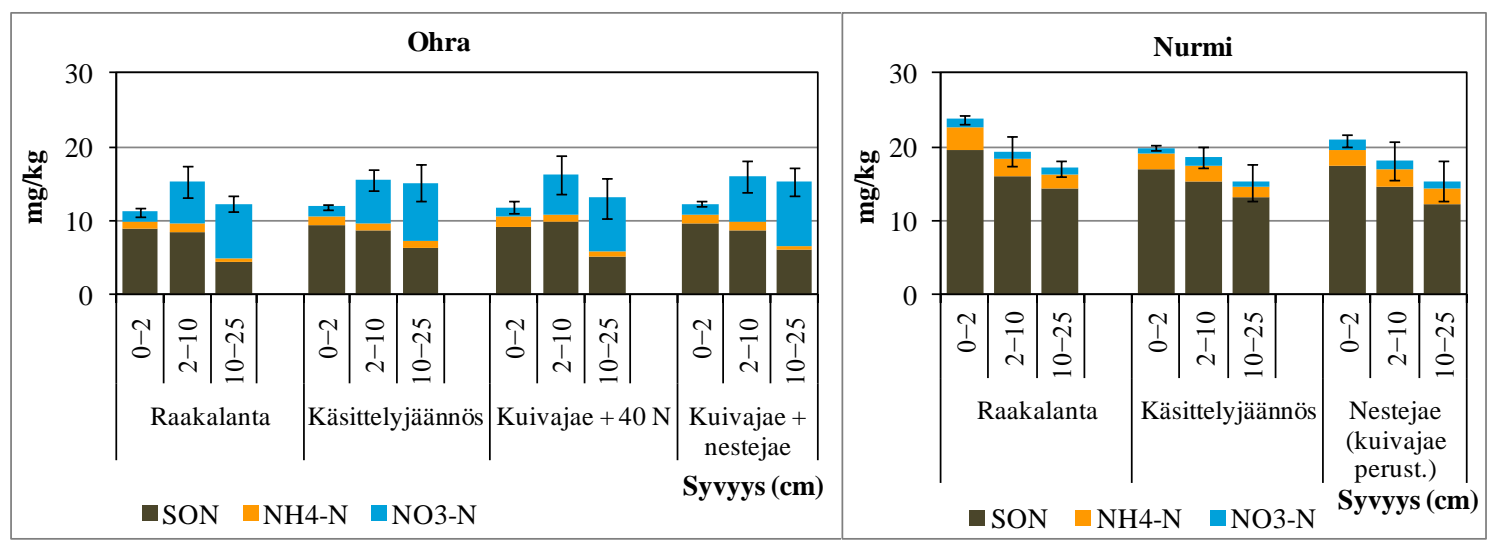

Kuva 4. KCl-uuttoisen mineraalitypen $\left(\mathrm{NH}_{4}-\mathrm{N}+\mathrm{NO}_{3}-\mathrm{N} \pm\right.$ keskihajonta) ja liukoisen orgaanisen typen (SON) määrä $(\mathrm{mg} / \mathrm{kg}) 0-2,2-10$ ja $10-25 \mathrm{~cm}: n$ maakerroksissa syksyllä 2011. SON = liukoinen kokonaistyppi $-\left(\mathrm{NH}_{4^{-}}\right.$ $\left.\mathrm{N}+\mathrm{NO}_{3}-\mathrm{N}\right)$.

\section{Johtopäätökset}

Orgaanisten lannoitteiden lannoitusvaikutus ja ravinnetaseet ja maan typen kierto poikkeavat toisistaan huomattavasti riippuen siitä, viljelläänkö nurmea vai viljaa. Tämä johtuu ennen kaikkea viljelymenetelmien eroista: monivuotisuus vs. yksivuotisuus, lannoitus- ja korjuukertojen määrä kasvukauden aikana, kasvien kyky käyttää ravinteita, koko kasvin vs. jyvien korjuu, sadon suuruus jne.

Tässä kokeessa ohran lannoitteena käytetyn käsittelyjäännöksen liukoisen typen lannoitusvaikutus oli keskimäärin korkeampi kuin raakalannan. Nurmella vastaavaa eroa ei havaittu, vaan kaikkien orgaanisten lannoitteiden hyväksikäyttö oli yhtä hyvä ja lähes väkilannoitetypen veroista. Vuosivaihtelu oli kuitenkin suurta, ja kuiva loppukesä 2010 näytti vaikuttavan heikentävästi raakalannan ja käsittelyjäännöksen typen hyväksikäyttöön. Nurmi on tehokas ravinteidenottaja, ja on huomionarvoista, että nurmikokeessa fosforitase oli negatiivinen kaikilla orgaanisilla lannoitteilla. Fosfori ei siis kumuloitunut maahan. Ohralla fosforitase oli lähes aina positiivinen, mutta ei kuitenkaan kovin suuri kuivaja nestejakeen yhdistelmälannoitusta lukuun ottamatta. Molemmissa kokeissa orgaanisten lannoitteiden sijoittaminen hillitsi helppoliukoisen fosforin rikastumista maan pintakerrokseen. Kokeiden tulokset raportoidaan kattavammin MTT Raportti-sarjassa (Virkajärvi ym. 2014).

\section{Kirjallisuus}

Luh Huang, C.-Y. \& Schulte, E.E. 1985. Digestation of plant tissue for analysis by ICP emission spectroscopy. Communications in Soil Science and Plant Analysis 16: 943-958.

Luostarinen, S., Paavola, T., Ervasti, S., Sipilä, I. \& Rintala, J. 2011. Lannan ja muun eloperäisen materiaalin käsittelyteknologiat. MTT Raportti 27. 64 s.

Luostarinen, S. \& Pyykkönen, V. 2013. Biokaasuteknologian perusteet. s. 10-20. Julkaisussa: Luostarinen, S. (toim.) Biokaasuteknologiaa maatiloilla 1: Biokaasulaitoksen hankinta, käyttöönotto ja operointi - käytännön kokemuksia MTT:n maatilakohtaiselta laitokselta. MTT Raportti 113. $97 \mathrm{~s}$.

Luostarinen, S. (Toim.). 2013. Biokaasuteknologiaa maatiloilla 1: Biokaasulaitoksen hankinta, käyttöönotto ja operointi - käytännön kokemuksia MTT:n maatilakohtaiselta laitokselta. MTT Raportti 113. $97 \mathrm{~s}$.

Paavola, T., Sipilä, I., Luostarinen, S. \& Rintala, J. 2011. Lannan ja muiden eloperäisten materiaalien prosessointi. s. 41-54. Julkaisussa: Luostarinen, S., Logrén, J., Grönroos, J., Lehtonen, H., Paavola, T., Rankinen, K., Rintala., J., Salo, T., Ylivainio, K. \& Järvenpää, M. (toim.). Lannan kestävä hyödyntäminen. MTT Raportti $21.164 \mathrm{~s}$.

Uusi-Kämppä, J. \& Heinonen-Tanski, H., 2008. Evaluating slurry broadcasting and injection to ley for phosphorus losses and fecal microorganisms in surface runoff. Journal of environmental quality 37: 2339-2350.

Virkajärvi, P., Hyrkäs, M., Räty, M., Pakarinen, T., Pyykkönen, V. ja Luostarinen, S. 2014. Biokaasuteknologiaa maatiloilla 2: Biokaasulaitoksen käsittelyjäännöksen hyödyntäminen lannoitteena. MTT Raporttisarja (käsikirjoitus).

Vuorinen, J. \& Mäkitie, O. 1955. The method of soil testing in use in Finland. Agrogeological Publications 63: 1-44.

Ylivainio, K. ja Turtola, E. 2009. Kotieläintalouden ylijäämäfosfori kasvintuotannossa. Teoksessa: Suomen kotieläintaloudenfosforikierto - säätöpotentiaali maatiloilla ja aluetasolla / Eila Turtola ja Kari Ylivainio (toim.). Maa- ja elintarviketalous 138: s. 65-160. 